\title{
THE U.S. PRESS ON WORLDWIDE DECOLONIZATION (1946-1948) ${ }^{1}$
}

\author{
Sergey O. Buranok \\ Samara State University of Social Sciences and Education, Samara, Russian Federation
}

\begin{abstract}
Introduction. The paper is devoted to the problem of developing approaches to studying decomposition of colonial system after 1945 in the U.S. press. The gradual disintegration of colonial empires connected with the growth of national movements and essential weakening of powers in mother countries became one of the most important results of World War II. The process of colonies disintegration was synchronous with genesis of new global opposition of the former allies on the anti-Hitlerite coalition. Methods and materials. The paper is based on materials of both democratic and republican editions of the U.S. press. The solution of the set research task required the use of chronological approaches allowing to study the multiaspect nature of the historical situation - the American society's attitude to decolonization, the national movements, etc. Analysis. The Cold War and search of the optimum relations with the closest ally of the USA - Great Britain demanded new approaches and views of decolonization process. At the same time, ambitions of the White House, on the one hand, supporting disintegration of colonial empires, and, on the other hand, diligently trying to replace the former empires led to a number of contradictions with the European states. All complexity of this situation was reflected also in the press trying to create understanding of the new process in which America was involved. During difficult search of an optimum way and a view of decolonization in the American press, several opposite points of view have been developed. Results. Thus, studying the attitude of the largest American editions and the most noticeable journalists is of interest to the analysis of how the USA power and population gradually realized the place of the country in the new system of the international relations, looked for optimum ways of interaction both with the closest allies, and with a number of the new independent states which appeared on the international scene.
\end{abstract}

Key words: the U.S. press, decolonization, Cold War, Third World, the USA, the USSR.

Citation. Buranok S.O. The U.S. Press on Worldwide Decolonization (1946-1948). Vestnik Volgogradskogo gosudarstvennogo universiteta. Seriya 4, Istoriya. Regionovedenie. Mezhdunarodnye otnosheniya [Science Journal of Volgograd State University. History. Area Studies. International Relations], 2018, vol. 23, no. 6, pp. 124-133. (in Russian). DOI: https://doi.org/10.15688/jvolsu4.2018.6.9

\section{ПРЕССА США О НАЧАЛЕ ПРОЦЕССА ДЕКОЛОНИЗАЦИИ В МИРЕ (1946-1948 ГГ.) ${ }^{1}$}

\section{Сергей Олегович Буранок}

Самарский государственный социально-педагогический университет, г. Самара, Российская Федерация

Аннотация. Статья посвящена проблеме выработки в прессе США подходов к процессу разрушения колониальной системы после 1945 г. и ее оценок. Одним из важных итогов Второй мировой войны стал постепенный распад колониальных империй, связанный с ростом национальных движений и существенным ослаблением держав-метрополий после войны. Процесс распада колоний по времени совпал с генезисом ового глобального противостояния бывших союзников по антигитлеровской коалиции. Статья базируется на материалах как демократических, так и республиканских изданий прессы США. Холодная война и поиск оптимальных отношений с ближайшим союзником США - Великобританией - требовали как от американского военно-политического руководства, так и от журналистов, новых подходов и взглядов на процесс деколонизации. Вместе с тем амбиции Белого дома, с одной стороны, поддерживающего распад колониальных империй, а с другой - старательно пытающегося заменить собой бывшие империи, привели к целому ряду 
противоречий с европейскими государствами. Вся сложность этой ситуации отражалась и в прессе, пытавшейся сформировать понимание данного нового процесса. В ходе сложного поиска оптимального пути и взгляда на деколонизацию в американской прессе выработалось несколько полярных точек зрения. Таким образом, изучение отношений крупнейших американских изданий и наиболее заметных журналистов представляет интерес для анализа того, как в США постепенно осознавали место страны в новой системе международных отношений, искали оптимальные пути взаимодействия как с ближайшими союзниками, так и с целым рядом новых независимых государств, заявивших о себе на международной арене.

Ключевые слова: пресса США, деколонизация, холодная война, третий мир, США, СССР.

Цитирование. Буранок С. О. Пресса США о начале процесса деколонизации в мире (1946-1948 гг.) // Вестник Волгоградского государственного университета. Серия 4, История. Регионоведение. Международные отношения. - 2018. - Т. 23, № 6. - C. 124-133. - DOI: https://doi.org/10.15688/jvolsu4.2018.6.9

Введение. Изучение особенностей подходов к анализу колониальной политики и колониальных империй в США после Второй мировой войны важно для более глубокого понимания процесса формирования американской внешней политики в условиях начала холодной войны, отношения американской прессы и политиков к национально-освободительным движениям, определению соотношения внутри- и внешнеполитического, социального, экономического и политического факторов накопления, систематизации и практического применения колониального знания до и во время деколонизации.

Методы. В методологии решения поставленной научной задачи, определяющее значение имеют проблемный и хронологический подходы, из которых проблемный является ведущим. Он представляется наиболее оптимальным, так как позволяет относительно полно во времени и пространстве охватить многоаспектность конкретно-исторической обстановки, в которой протекал процесс формирования отношения в американском обществе к деколонизации, национально-освободительным движениям и колониальным империям. С помощью данных подходов проанализированы ведущие периодические издания США за 1945-1948 гг.: «Chicago Daily Tribune», «Christian Science Monitor», «Daily Boston Globe», «New York Times», «Washington Post». К демократическим изданиям относятся: «Christian Science Monitor», «Daily Boston Globe», «New York Times». К Республиканским: «Chicago Daily Tribune», «Washington Post».

Анализ. Осенью-зимой 1945 г. ведущие журналисты США не считали свою державу прямым соперником Великобритании в странах третьего мира [46, p. 589]. А британский колониальный опыт еще не в полной мере попал в фокус внимания американских СМИ [21, p. $24-46 ; 24$, p. $345-363 ; 47$, p. 462-511; 55, p. 388-420]. В газетных публикациях существовала и обладала определенной популярностью идея отказаться от прямого вмешательства в европейские дела, признавая приоритет влияния СССР: «Вторая мировая война подняла СССР на вершину могущества. Теперь Россия - величайшая дипломатическая сила на евразийском пространстве, контролирующая мир от Атлантического до Тихого океана. Гегемония СССР в Европе - очевидна» [56, p. 3]. Широко обсуждался вариант сохранения ключевых сфер влияния: советской, британской и французской, возможно, даже голландской и бельгийской. Наиболее точно эту идею обосновал У. Липпман ведущий международный обозреватель газеты «Washington Post», который считал, что нужно сохранить хрупкий баланс между политикой самоопределения (от нее никто из серьезных журналистов и экспертов не предлагал отказываться: А. Сульцбергер, Э. Линдли, С. Уэллса, Д. Фрост) и политикой деколонизации. У. Липпман предлагал своеобразное решение этой дилеммы, назвав его «упорядоченной деколонизацией». Согласно идее Липпмана демонтаж колониальных систем не повредит отношениям США со своими европейскими союзниками [26, p. 3].

У. Липпман предлагал сосредоточиться на более важном вопросе: «основной проблемой Америки является то, что во всех регионах мира, где существует опасный международный беспорядок, британское влияние на эти регионы является более древним, более прямым, более доверенным, чем американское» $[27$, p. 4]. Новый рецепт Липпмана выглядел 
весьма привлекательным в общем контексте американского общественного дискурса: не самим решать проблемы Индонезии, Малайи, Ближнего Востока и Индии, а через взаимодействие с существующей, как писал журналист, «имперской властью» [18, p. 1-22]. Так, американцы не откажутся от принципов Атлантической хартии и одновременно продемонстрируют европейским союзникам свою поддержку и понимание их колониальных интересов. Все чаще в публикациях американских журналистов звучат слова «порядок» и «стабильность» в странах третьего мира вместо немедленной «свободы и самоопределения» для африканских и азиатских народов.

Причин таких перемен в колониальной дискуссии несколько. Во-первых, в конце 1945 начале 1946 гг. национальные движения в колониях, особенно в Индокитае и Индонезии, заметно активизировались [20, p. 30-44].

Во-вторых, все большую опасность в глазах американских журналистов приобретало сближение и в идейном, и в практико-политическом плане антиколониальных сил Азии с советским блоком. Именно как противовес этому сближению и рассматривалась журналистами возможность использования сил и ресурсов (но пока не опыта) Великобритании. В плане преемственности колониального опыта американские комментаторы 1946-1947 гг. считали, что опыт США по управлению Филиппинами более универсальный, более эффективный, а, главное, больше соответствует декларируемым принципам, чем опыт какойлибо европейской державы [20, p. 3-9]. Другим довольно неожиданным примером эффективности американской модели управления в 1946 г. стала в американских СМИ Япония. Как и Филиппины, Япония служила Америке примером того, как колониальные державы во всем мире должны подражать США. Для журналистов американская администрация в Японии показала, что даже так называемые продвинутые туземцы, такие как японцы, нуждались в твердой руке и американском руководстве для раскрытия своего потенциала в создании государственных институтов и гражданского общества. Япония воспринималась сразу после войны в США как образец экспорта американской системы управления, демократии и свободы.
Эти два примера (Филиппины и Япония) позволяли прессе США делать весьма широкие обобщения, что подобным же образом возможно привести к миру и стабильности остальные азиатские народы. И сравнение в 1946 г. американских усилий в Японии (всего год работы американской администрации) и в Палестине, Бирме, Индии (десятилетия господства британских властей) позволяло журналистам США с уверенностью говорить об архаичности, отсталости и неэффективности колониального опыта Великобритании [4, p. 1].

В-третьих, очевидная слабость европейских держав в колониях позволяла американским комментаторам и экспертам довольно свободно рассуждать о будущей (причем, в ближайшей перспективе) роли США в третьем мире: от арбитра споров между зависимыми территориями и метрополиями до участника силовых акций в странах третьего мира $[27$, p. 8].

Сравнивая собственно американский опыт по управлению азиатскими территориями с европейским, американские журналисты видели определенное противоречие: длительные усилия старых колониальных империй так и не позволили создать условия для государственности и гражданского общества в государствах Азии, тогда как быстрая работа военных и чиновников США демонстрировала заметные успехи. Выход из этого противоречия был найден не в полном отрицании европейского опыта, а в несколько искусственном разделении колониальных народов: на те, где уместно учитывать исторический опыт Европы, и на те, где такие действия неуместны.

Решение этого нового вопроса все больше рассматривалось участниками дискуссии как особая форма поддержки для Западной Европы: США сохранят влияние на процессы деколонизации в регионах, где порядок и стабильность возможно сохранить уже без европейского вмешательства, и одновременно поддержат власть старых империй в регионах, где они являются гарантом стабильности.

В конце 1945-1946 гг. наблюдаются тенденции в прессе США по изменению позиции заинтересованного наблюдателя на активного участника решения колониальной проблемы. Наибольшее внимание журналистов было 
сосредоточено на Ближнем Востоке и ЮгоВосточной Азии [3, p. 648-670]. Общий настрой американских редакторов и комментаторов заключался в том, что они признавали: для того чтобы поддерживать порядок и стабильность на Ближнем Востоке, необходимы конкретные действия со стороны США, но одновременно указывалось, что Великобритания и Франция обладают более длительной историей своих интересов в этом регионе, более солидным опытом, большими знаниями о Ближнем Востоке, следовательно имеют законное право в глазах мировой и в том числе американской общественности на вмешательство [31, p. 2]. По этому поводу Барнет Новер, один из редакторов «Washington Post», заявил, что «разрушение или внезапный роспуск британской империи был бы серьезным ударом по безопасности США, демократии и надежде на получение упорядоченного мира» [28, p. 4].

На первый план в начале 1946 г. выходит не демонтаж колониальной системы как противоречащей принципам Атлантической хартии, a ее глобальная перестройка с сохранением, сугубо временным, доминирующего положения Великобритании и Франции в регионах, где США не смогут сразу обеспечить стабильность. Подобное изменение подходов настораживало американских экспертов: владелец «New York Times» А. Сульцбергер писал: «Европа нам не доверяет. Часто можно услышать, что Соединенные Штаты наследуют непопулярные методы XIX века» [51, p. 5].

После завершения Второй мировой войны пресса США начинает процесс пересмотра своего отношения к колониальной теме. СМИ США явно отходят от позиций критицизма и переходят к более глубокому и всестороннему анализу как самой системы в целом, так и британского опыта управления колониями, открыто признавая в этом вопросе исторические связи, опыт решения конфликтов и опыт управления местными элитами могут оказаться более полезными, чем верность абстрактным принципам [17, p. 353-381].

Однако с этим фактором связан другой сложный момент, на который указывал У. Липпман: последствия Второй мировой войны в Европе - экономические, политические, пси- хологические - делают невозможным сохранение ни одной из колониальных империй (на это, по мнению журналиста, нет ни военных, ни материальных ресурсов). А быстрое развитие национально-освободительных движений перечеркивает все европейские иллюзии о мирном возвращении колониальных администраций.

И в этом наборе проблем Липпман очень пристальное внимание уделял психологии европейских лидеров: военный престиж Европы после 1945 г. резко упал, и лидеры Великобритании, Франции, Голландии могут попытаться вернуть часть данного престижа путем колониальных войн, чему были уже прямые аналогии в истории $[1, \mathrm{p} .145]$. Но, не имея на подобные конфликты сил, опыта, выдержки, европейские державы и их лидеры только усложнят международную обстановку. Таким образом, американский эксперт подчеркивал, что самосознание европейских политиков, их самовосприятие могут (и очень скоро) стать серьезной проблемой $[27$, p. 5].

А. Сульцбергер и М. Чайлдс хотя и чуть позже (в ноябре - декабре 1945 г.), тоже обратились к настроениям и психологии европейцев. А. Сульцбергер писал, что в настоящий момент многое зависит от Франции, ведь часть ее колоний поддержали режим Виши, следовательно, для нового правительства возращение полного контроля над территориями в Азии и Африке - это дело принципиальное, но невыполнимое, и оно станет роковым для Франции предприятием [48, p. 3].

М. Чайлдс был наиболее пессимистичным в своих оценках. На примере голландской колониальной империи он рассуждал, что у Нидерландов нет сил даже собственную страну восстановить, но без ресурсов Индонезии метрополия обречена. Единственный выход Голландии - обратиться за помощью к Великобритании, что может привести к созданию новых блоков европейских держав для усмирения антиколониальных движений. Тогда роль США в новой системе международных отношений окажется весьма туманной $[28$, p. 6].

Из этого американские журналисты делали один важный вывод: необходимо не допустить коллективных действий стран Европы для поддержания стабильности в колони- 
ях без согласования с Соединенными Штатами, для чего президенту США, по мнению комментаторов, надлежит сделать упор на военно-экономический и моральный фактор. Причем последний представлялся американским экспертам чрезвычайно значимым и для его эксплуатации и актуализации они прибегали к самым широким историческим аналогиям, доказывая, что в середине XX в. немыслимо реставрировать систему и порядки середины XVIII века [28, p. 6].

На рубеже 1945-1946 гг. пресса США окончательно определилась с перечнем проблем и угроз, которые Америка может решить в контексте перестройки старой колониальной системы. Это и экономическая помощь как зависимым народам, так и европейским державам, и распространение демократии в Азии, и контроль над национальными движениями. Каждая из этих проблем включала в себя несколько различных подходов, сторонники которых на страницах газет и журналов вели настоящую борьбу за доказательство собственного видения американской роли в будущем постколониальном мире.

Если период 1945-1946 гг. был для американских журналистов временем напряженных дискуссий и поиска оптимальной модели взаимодействия США и «старых империй», то период 1947-1949 гг. стал временем апробации новых форм сотрудничества США и Европы в контексте деколонизирующегося мира, роста влияния СССР, усиления национальных движений и целого ряда международных кризисов начала холодной войны.

Иранский кризис сразу стал инструментом в общественно-политической дискуссии американских комментаторов по международным проблемам с самого начала 1946 г. до конца 1948 г., и реакция США на деколонирующий мир в этот период быстро эволюционировала. Так, роль США в первый год кризиса была практически такой же, как и на другие проблемы колониальных владений с 1945 г.: Липпман считал, что Иран является, прежде всего, многовековой проблемой англо-российских отношений, следовательно, у Великобритании накоплен колоссальный опыт решения подобных вопросов, а задача США - быть лишь посредником, поддерживая европейского союзника [30, p. 4].
Но к 1947-1948 гг. позиции и взгляды журналистов изменились. Липпман уже пишет, что на иранский кризис необходимо смотреть более широко как на выбор между коммунизмом и демократией. При таком подходе Липпман уже был уверен: не важно, есть ли у США интересы в каком-либо регионе, ускорит или затормозит американское вмешательство антиколониальные процессы, важно другое поставить под контроль международную активность СССР [37, p. 3].

Видно, что американские журналисты встраивали свои концепции уже в доктрину Трумэна, обсуждение ее основных тезисов породило новую дискуссию в рамках колониальной проблематики. Еще в 1946 г. в СМИ США стали появляться предположения о том, что Великобритания не сможет долго помогать Греции и Турции «сдерживать партизанские силы внутри стран» $[5$, p. $13 ; 6$, p. 26]. Читателям на протяжении 1946 г. доказывалась идея, что проблема Турции и Греции стала шире, чем исключительно британское дело: «Соединенные Штаты выдвинули определенный компромисс в российско-британском тупике по Греции перед Советом Безопасности Организации Объединенных Наций, предложив, чтобы специальный комитет расследовал конфликт» $[43$, р. 7].

Параллельно с этим публиковались многочисленные статьи о значительной степени «красной угрозы» для Греции и различных инициативах Великобритании по выходу из конфликта [13, p. $1 ; 14$, p. 1; 41, p. 1; 42, p. 1]. Но американские комментарии данных инициатив неизменно указывали на их архаичность и бесперспективность.

Последнее обстоятельство особенно тщательно анализировалось журналистами и экспертами: на добровольное намерение Великобритании отказаться от силового решения проблемы в пользу посредничества США указывали С. Уэллс, У. Липпман, Б. Новер [32, p. 2]. СМИ США к началу 1947 г. пришли к выводу, что Великобритания больше не способна ни контролировать ситуацию в Средиземном море, ни осуществлять там интервенцию, ни проводить полицейские операции. Добровольный отказ от главной роли в решении конфликта в Греции, по мнению журналистов США, стал своеобразным сигналом: британ- 
ская политика в колониальных делах попадает в большую зависимость от американских интересов, от характера советско-американского противостояния, что радикально изменяет всю старую базу международных отношений.

Характерно, что в публикациях 1946 г. греческий кризис был представлен в США в контексте колониальной риторики: журналисты и политики проводили параллели между положением в Греции и Индонезии. Кроме того, в прессе часто сравнивали подходы к решению палестинской проблемы с греческой, анализировали опыт Великобритании в Греции и Индии. Это делалось совершенно сознательно, так как наводило читателей (и самих журналистов) на мысль, что если Великобритания так легко передает инициативу в решении греческого вопроса, то следовательно она может и должна так же поступить и в Индонезии, Палестине, Африке, Индии, на Тихом океане (терминология в СМИ при характеристике происходящих там процессов была идентичной) [22, p. 298]. Доктрина Трумэна стала своеобразным ответом на публикации в американских СМИ, призывающие воспользоваться британским предложением и взять решение конфликта в Греции в «американские руки» [25, р. 136].

12 марта 1947 г. Г. Трумэн попросил Конгресс предоставить 400 млн долларов на прямую открытую помощь, которая позволит Греции и Турции сохранить свой национальный суверенитет и одновременно остаться в сфере влияния Запада. И политики США, и пресса отнеслись к этому как к событию чрезвычайной важности: Великобритания официально отказалась от своей роли в качестве главной движущей силы глобальной стабильности, передав (хотя лишь в части одного региона) данные функции Соединенным Штатам [8, p. 1; 15 , p. $12 ; 16$, p. 1].

В марте 1947 г. Липпман писал о Британии как «нейтрализованной мировой силе», но однозначно положительные выводы из этого он делать не спешил [33, p. 3]. М. Чайлдс, наоборот, видел ситуацию после речи Трумэна как самую благоприятную: «Колониальные народы во всем мире давно двигались к независимости. И это был долг Америки - дать им руководство и помощь. В этом наша мировая роль. Это наша обязанность и на Даль- нем Востоке, и на Среднем Востоке» [32, p. 5]. Видно, журналист всего в нескольких выражениях связал ситуацию и в Греции, и в Индокитае, и в Индонезии, и в Иране, плавно проведя преемственность (напрямую и не называя их) от «14 пунктов Вильсона» и Атлантической хартии до доктрины Трумэна [47, p. 1327-1351; 51, p. 335-352].

И хотя кризисы в Иране и Греции не были чисто колониальными проблемами, они показали для журналистов и экспертов США (М. Чайлдс, У. Липпман, С. Уэллс, Б. Новер, Э. Линдли) возможный набор инструментов и методов не только по решению проблем зависимых народов, но и, что немаловажно, продемонстрировали новый путь развития дискуссии в обществе: основополагающей базой (терминологической, методологической, идеологической) стала не Атлантическая хартия, а доктрина Трумэна. Такая перестройка и эволюция позиции американских журналистов пришлась на начальный этап холодной войны, который, как они указывали, был отмечен первой волной деколонизации.

Пресса США в период 1947-1948 гг. с удовлетворением отмечала обретение независимости от Британской империи Индии, Пакистана, Бирмы, Цейлона, провозглашение независимости Индонезией. Такой вариант развития событий в Азии предсказывал С. Уэллс (бывший заместитель государственного секретаря США) еще в 1946 г. [31, p. 4] В публикациях «Chicago Daily Tribune» 1947 г. всячески подчеркивались совместные усилия США, Великобритании и «народа Бирмы» для получения независимости [7, p. 17; 9, p. 7]. «Los Angeles Times» в этот же период приветствовала «превращение экзотической Бирмы в независимую страну» [44, p. $4 ; 45$, p. 1].

С. Дэвис из «Christian Science Monitor» назвал решение премьер-министра Великобритании К. Эттли предоставить Бирме независимость в начале 1948 г. «экстраординарным событием в истории освобождения колониальных народов» [12, p. 6].

Новости из Индии и Пакистана делали состояние американских журналистов близким к эйфории: СМИ неизменно отмечали, какой Соединенные Штаты проделали долгий путь дипломатической борьбы с использова- 
нием политических, экономических, моральных методов, чтобы подвести Великобританию к осознанию необходимости именно таких действий в отношении колоний. Только У. Липпман и К. Дэниэль в 1947 г. осторожно спрашивали: можно ли доверять даже «политически опытным колониальным народам вести свои дела и смогут ли они так же эффективно решать региональные проблемы, как старые колониальные империи»? [37, p. 8; 52, p. 2]. У названных журналистов наибольшие опасения вызывала возможность начала конфликтов между новыми азиатскими государствами, которые лишились привычного контроля из Великобритании, Франции, Голландии, Бельгии. Европы.

Однако в 1948 г. данные опасения уже выглядели слишком наивными: деколонизированные народы начинают проявлять повышенный интерес к социализму [2, p. 415-444]. Так, уже в июне 1948 г. «Chicago Daily Tribune» опубликовала серию мрачных прогнозов: «Бирма становится красной»; «Бирма поддержит Россию»; «Бирма планирует строить социализм»; «Конец капитализма» [10, p. $18 ; 11$, p. 23]. С середины 1948 г. американские журналисты практически забывают рассуждения о важности деколонизации, соблюдении завещания В. Вильсона и самоопределении для зависимых народов. Большинство информационного пространства (по колониальному вопросу) стала занимать проблема: как не допустить переход новых азиатских государств к социализму и коммунизму [23, p. 331-352].

Если в период 1945-1947 гг. антиколониальные движения в Азии рассматривались СМИ США как основные в процессе разрушения устаревшего европейского империализма в традициях XVIII в., то с 1947-1948 гг. комментаторы в США начинают видеть в национальных движениях одну из угроз мировой стабильности и порядку. Об этом У. Липпман писал в середине 1947 г.: «Индонезия, Индокитай, Бирма, возможно даже Индия и Пакистан чаще смотрят в сторону Москвы, чем на Лондон или Вашингтон. И на Ближнем Востоке, ни в Египте, ни в Сирии, ни в Ираке не господствуют те классы, на которые раньше опирался Лондон» [38, p. 9]. В своих прогнозах У. Липпман предвосхищал события следующего, 1948 года.
Быстрая переориентация бывших колониальных территорий в Азии в сторону СССР потребовала от экспертного и журналистского сообщества США таких же быстрых действий, связанных с анализом и прогнозированием ситуации в странах третьего мира. Неслучайно, что именно в 1948 г. в ЦРУ появляется отчет о влиянии распада колониальной системы на безопасность США [53].

Результаты. Можно предположить, что впервые в процессе эволюции колониального вопроса в США американские журналисты, эксперты, разведывательное сообщество, дипломаты оказались не только в рамках одного проблемного поля с одинаковыми аналитическими задачами, но и начали взаимодействовать с целью выработки наиболее оптимального решения данных задач: какой должна быть политика и риторика США в отношении колониальных империй и зависимых народов, чтобы не подтолкнуть их к советскому блоку, не лишиться европейских союзников, сохранить за США приоритетную роль в решении глобальных проблем. И с этим связан еще один момент в эволюции оценок журналистами США процесса деколонизации: к 1948 г. американские эксперты стали связывать все национальные движения в колониях с коммунизмом, рассуждая о национальных лидерах как об «агентах Кремля». Данная черта очень быстро превратится не просто в стереотип, а в один из базовых элементов американской оценки политических процессов в постколониальном мире, причем на самую длительную перспективу (до середины 1980-х гг.) [48, p. 103].

Теоретическую базу под новые реалии деколонизирующегося мира попробовал подвести в 1948 г. У. Липпман, писавший, что Советский Союз очень вовремя включился в борьбу за «третий мир», когда США и старые колониальные империи еще не выработали единого и общего курса. Причем, подчеркивал журналист, «советская модель» активно предлагается не Европе, а колониальным народам, которые «слишком примитивны, слишком унижены и слишком безграмотны» для формирования демократических правительств и гражданских свобод [40, p. 11]. Тезис Липпмана о «примитивности» был очень быстро воспринят другими журналистами для объяснения популярнос- 
ти коммунистических идей в постколониальном мире. Этот аргумент о «примитивизме» напрямую выходил из европейских аргументов о колонизации XVIII-XIX веков. Он вызвал обоснование неоколониального патернализма в отношении стран третьего мира, а также видение его как места «примитивных» идеалов и институтов, которые могли бы оказаться угрозой Западу [40, p. 11].

\section{ПРИМЕЧАНИЕ}

${ }^{1}$ Исследование выполнено за счет гранта Российского научного фонда (проект № 17-78-20029 «Колониальное знание в постколониальную эпоху: историческое моделирование асимметричных конфликтов »).

\section{СПИСОК ЛИТЕРАТУРЫ}

1. Albertini, R. Decolonization: The Administration and Future of the Colonies, 1919-1960 / R. Albertini. - N. Y. : Doubleday, 1971.-700 p.

2. Bennett, H. "A very salutary effect": The Counter-Terror Strategy in the Early Malayan Emergency, June 1948 to December 1949 / H. Bennett // Journal of Strategic Studies. - 2009. - № 3. P. $415-444$.

3. Cesarani, D. The war on terror that failed: British counter-insurgency in Palestine 1945-1947 and the "Farran Affair" / D. Cesarani // Small Wars \& Insurgencies. - 2012. - № 4/5. - P. 648-670.

4. Chicago Daily Tribune. - 1946. - Apr. 14.

5. Chicago Daily Tribune. -1946 . - Dec. 4.

6. Chicago Daily Tribune. - 1946. - Dec. 6.

7. Chicago Daily Tribune. - 1947. - Febr. 9.

8. Chicago Daily Tribune. - 1947. - Mar. 14.

9. Chicago Daily Tribune. - 1947. - Oct.18.

10. Chicago Daily Tribune. - 1948. - June 15.

11. Chicago Daily Tribune. - 1948. - June 16.

12. Christian Science Monitor. - 1947. - Oct. 30.

13. Daily Boston Globe. - 1946. - Febr. 7.

14. Daily Boston Globe. - 1946. - Dec. 4.

15. Daily Boston Globe. - 1947. - Mar. 13.

16. Daily Boston Globe. - 1947. - Mar. 14.

17. Dixon, P. Hearts and Minds? British CounterInsurgency from Malaya to Iraq / P. Dixon // Journal of Strategic Studies. - 2009. - № 3. - P. 353-381.

18. Gouda, F. The Gendered Rhetoric of Colonialism and Anti-Colonialism in Twentieth-Century Indonesia / F. Gouda // Indonesia. - 1993. - № 55. - P. 1-22.

19. Groen, P. Militant Response: The Dutch use of military force and the decolonization of Dutch
East Indies 1945-1950 / P. Groen // The Journal of Imperial and Commonwealth History. - 1993. Vol. 21. - P. 30-44.

20. Gurtov, M. The United States against the Third World / M. Gurtov. - N. Y. : Praeger, 1974.-260 p.

21. Hodge, J. M. British Colonial Expertise, PostColonial Careering and the Early History of International Development / J. M. Hodge // Journal of Modern European History. - 2010. - № 1. - P. 24-46.

22. Howard, J. "A New Kind of War": America's Global Strategy and the Truman Doctrine in Greece / J. Howard. - N. Y. : Oxford University Press, 1989. $360 \mathrm{p}$.

23. Kanet, R. E. The Superpower Quest for Empire: The Cold War and Soviet Support for "Wars of National Liberation" / R. E. Kanet // Cold War History. 2006. - № 3. - P. 331-352.

24. Kennedy, D. Imperial history and post-colonial theory / D. Kennedy // The Journal of Imperial and Commonwealth History. - 1996. - № 3. - P. 345-363.

25. Lee, E. Congress and the Origins of the Cold War: The Truman Doctrine / E. Lee // World Affairs. 1989. - Vol. 151, № 3. - P. 131-141.

26. Lippmann, W. Today and Tomorrow / W. Lippmann // Washington Post. - 1945. - Apr. 19. 27. Lippmann, W. Today and Tomorrow / W. Lippmann // Washington Post. - 1945. - May 22. 28. Lippmann, W. Today and Tomorrow

/ W. Lippmann // Washington Post. - 1945. - Oct. 27. 29. Lippmann, W. Today and Tomorrow / W. Lippmann // Washington Post. - 1945. - Oct. 30. 30. Lippmann, W. Today and Tomorrow / W. Lippmann // Washington Post. - 1945. - Nov. 2. 31. Lippmann, W. Today and Tomorrow

/ W. Lippmann // Washington Post. - 1945. - Dec. 7. 32. Lippmann, W. Today and Tomorrow /W. Lippmann // Washington Post. - 1946. - Febr. 28. 33. Lippmann, W. Today and Tomorrow

/ W. Lippmann // Washington Post. - 1946. - Nov. 27. 34. Lippmann, W. Today and Tomorrow

/ W. Lippmann // Washington Post. - 1947. - Mar. 4. 35. Lippmann, W. Today and Tomorrow / W. Lippmann // Washington Post. - 1947. - Mar. 8. 36. Lippmann, W. Today and Tomorrow / W. Lippmann // Washington Post. - 1947. - Mar. 7. 37. Lippmann, W. Today and Tomorrow / W. Lippmann // Washington Post. - 1947. - June 7. 38. Lippmann, W. Today and Tomorrow

/ W. Lippmann // Washington Post. - 1947. - June 17. 39. Lippmann, W. Today and Tomorrow

/ W. Lippmann // Washington Post. - 1948. - Jan. 28. 40. Lippmann, W. Today and Tomorrow

/ W. Lippmann // Washington Post. - 1948. - June 4. 41. Los Angeles Times. - 1946. - Febr. 2. 42. Los Angeles Times. - 1946. - Febr. 7. 43. Los Angeles Times. - 1946. - Sept. 19. 
44. Los Angeles Times. - 1948. - Jan. 4.

45. Los Angeles Times. - 1947. - Jan. 29.

46. Louis, W. Ends of British Imperialism: The Scramble for Empire, Suez, and Decolonization /W. Louis. - N. Y. : I.B. Tauris, 2006. - 1032 p.

47. Louis, W. R. The imperialism of decolonization / W. R. Louis, R. Robinson // The Journal of Imperial and Commonwealth History. - 1994. - № 3. - P. 462-511.

48. MacFarlane, S. Superpower Rivalry and Third World Radicalism: The Idea of National Liberation. Baltimore / S. MacFarlane. - Baltimore : The Johns Hopkins University Press, 1985. - 236 p.

49. Manela, E. Imagining Woodrow Wilson in Asia: Dreams of East-West Harmony and the Revolt against Empire in 1919 / E. Manela, E. Manela // The American Historical Review. - 2006. - № 5. - P. 1327-1351.

50. New York Times. - 1945. - Dec. 25.

51. New York Times. - 1946. - Jan. 23.

52. New York Times. - 1947. - Oct. 12.

53. ORE 25-48. The Break-Up of the Colonial Empires and its Implications for US Security / Central Intelligence Agency. - 1948. - Sept. 3.

54. Van Der Eng, P. Marshall Aid as a Catalyst in the Decolonization of Indonesia 1947-1949 / P. Van Der Eng // Journal of Southeast Asian Studies. - 1988. № 2. - P. 335-352.

55. Wolfe, P. History and Imperialism: A Century of Theory, from Marx to Postcolonialism / P. Wolfe // The American Historical Review. - 1997. - № 2.P. 388-420.

56. Zanesville Signal. - 1945. - Sept. 9.

\section{REFERENCES}

1. Albertini R. Decolonization: The Administration and Future of the Colonies, 1919-1960. New York, Doubleday, $1971.700 \mathrm{p}$.

2. Bennett H. "A very salutary effect": The Counter-Terror Strategy in the Early Malayan Emergency, June 1948 to December 1949. Journal of Strategic Studies, 2009, no. 3, pp. 415-444.

3. Cesarani D. The war on terror that failed: British counter-insurgency in Palestine 1945-1947 and the "Farran Affair". Small Wars \& Insurgencies, 2012, no. 4/5, pp. 648-670.

4. Chicago Daily Tribune, 1946, April 14.

5. Chicago Daily Tribune, 1946, December 4.

6. Chicago Daily Tribune, 1946, December 6.

7. Chicago Daily Tribune, 1947, February 9.

8. Chicago Daily Tribune, 1947, March 14.

9. Chicago Daily Tribune, 1947, October 18.

10. Chicago Daily Tribune, 1948, June 15.

11. Chicago Daily Tribune, 1948, June 16.

12. Christian Science Monitor, 1947, October 30.

13. Daily Boston Globe, 1946, February 7.
14. Daily Boston Globe, 1946, December 4.

15. Daily Boston Globe, 1947, March 13.

16. Daily Boston Globe, 1947, March 14.

17. Dixon P. Hearts and Minds? British CounterInsurgency from Malaya to Iraq. Journal of Strategic Studies, 2009, no. 3, pp. 353-381.

18. Gouda F. The Gendered Rhetoric of Colonialism and Anti-Colonialism in TwentiethCentury Indonesia. Indonesia, 1993, no. 55, pp. 1-22.

19. Groen P. Militant Response: The Dutch use of military force and the decolonization of Dutch East Indies 1945-1950. The Journal of Imperial and Commonwealth History, 1993, vol. 21, pp. 30-44.

20. Gurtov M. The United States against the Third World. New York, Praeger, 1974. 260 p.

21. Hodge J.M. British Colonial Expertise, PostColonial Careering and the Early History of International Development. Journal of Modern European History, 2010, no. 1, pp. 24-46.

22. Howard J. "A New Kind of War": America's Global Strategy and the Truman Doctrine in Greece. New York, Oxford University Press, 1989. 360 p.

23. Kanet R.E. The Superpower Quest for Empire: The Cold War and Soviet Support for "Wars of National Liberation". Cold War History, 2006, no. 3, pp. 331-352.

24. Kennedy D. Imperial history and post-colonial theory. The Journal of Imperial and Commonwealth History, 1996, no. 3, pp. 345-363.

25. Lee E. Congress and the Origins of the Cold War: The Truman Doctrine. World Affairs, 1989, vol. 151 , no. 3 , pp. 131-141.

26. Lippmann, W. Today and Tomorrow. Washington Post, 1945, April 19.

27. Lippmann, W. Today and Tomorrow. Washington Post, 1945, May 22.

28. Lippmann, W. Today and Tomorrow. Washington Post, 1945, October 27.

29. Lippmann, W. Today and Tomorrow. Washington Post, 1945, October 30.

30. Lippmann, W. Today and Tomorrow. Washington Post, 1945, November 2.

31. Lippmann, W. Today and Tomorrow. Washington Post, 1945, December 7.

32. Lippmann, W. Today and Tomorrow. Washington Post, 1946, February 28.

33. Lippmann, W. Today and Tomorrow. Washington Post, 1946, November 27.

34. Lippmann, W. Today and Tomorrow. Washington Post, 1947, March 4.

35. Lippmann, W. Today and Tomorrow. Washington Post, 1947, March 8.

36. Lippmann, W. Today and Tomorrow. Washington Post, 1947, March 7.

37. Lippmann, W. Today and Tomorrow. Washington Post, 1947, June 7. 
38. Lippmann, W. Today and Tomorrow. Washington Post, 1947, June 17.

39. Lippmann, W. Today and Tomorrow. Washington Post, 1948, January 28.

40. Lippmann, W. Today and Tomorrow. Washington Post, 1948, June 4.

41. Los Angeles Times, 1946, February 2.

42. Los Angeles Times, 1946, February 7.

43. Los Angeles Times, 1946, September 19.

44. Los Angeles Times, 1948, January 4.

45. Los Angeles Times, 1947, January 29.

46. Louis W. Ends of British Imperialism: The Scramble for Empire, Suez, and Decolonization. New York, I.B. Tauris, 2006. $1032 \mathrm{p}$.

47. Louis W.R., Robinson R. The imperialism of decolonization. The Journal of Imperial and Commonwealth History, 1994, no. 3, pp. 462-511.

48. MacFarlane S. Superpower Rivalry and Third World Radicalism: The Idea of National Liberation.
Baltimore. Baltimore, The Johns Hopkins University Press, 1985. $236 \mathrm{p}$.

49. Manela E., Manela E. Imagining Woodrow Wilson in Asia: Dreams of East-West Harmony and the Revolt against Empire in 1919. The American Historical Review, 2006, no. 5, pp. 1327-1351.

50. New York Times, 1945, December 25.

51. New York Times, 1946, January 23.

52. New York Times, 1947, October 12.

53. ORE 25-48. The Break-Up of the Colonial Empires and its Implications for US Security. Central Intelligence Agency, 1948, September 3.

54. Van Der Eng P. Marshall Aid as a Catalyst in the Decolonization of Indonesia 1947-1949. Journal of Southeast Asian Studies, 1988, no. 2, pp. 335-352.

55. Wolfe P. History and Imperialism: A Century of Theory, from Marx to Postcolonialism. The American Historical Review, 1997, no. 2, pp. 388-420.

56. Zanesville Signal, 1945, September 9.

\section{Information about the Author}

Sergey O. Buranok, Doctor of Sciences (History), Professor of Department of World History, Law and Teaching Methods, Samara State University of Social Sciences and Education, Maksima Gorkogo St., 65\67, 443099 Samara, Russian Federation, witch-king-1@mail.ru, https://orcid.org/0000-0001-8307-9428

\section{Информация об авторе}

Сергей Олегович Буранок, доктор исторических наук, профессор кафедры всеобщей истории, права и методики обучения, Самарский государственный социально-педагогический университет, ул. Максима Горького, 65/67, 443099 г. Самара, Российская Федерация, witch-king-1@mail.ru, https://orcid.org/0000-0001-8307-9428 